\title{
Impact of Substance Use Disorder on Presentation of Schizophrenia
}

\author{
Suprakash Chaudhury ${ }^{1 *}$, Sai Krishna Tikka² and Ajay Kumar Bakhla ${ }^{3}$ \\ ${ }^{1}$ Department of Psychiatry, Pravara Institute of Medical Sciences (Deemed University), Rural Medical College, India \\ ${ }^{2}$ Department of Psychiatry, Central Institute of Psychiatry, Ranchi, Jharkhand, India \\ ${ }^{3}$ Department of Psychiatry, Rajendra Institute of Medical Sciences (RIMS), Ranchi, Jharkhand, India
}

*Corresponding author: Suprakash Chaudhury, Department of Psychiatry, Pravara Institute of Medical Sciences (Deemed University), Rural Medical College, India, Tel: 9370386496; E-mail: suprakashch@gmail.com

Citation: Chaudhury S, Krishna ST, Kumar AB (2016) Impact of Substance Use Disorder on Presentation of Schizophrenia. Dual Diagn Open Acc 1:7. doi: 10.21767/2472-5048.100007

Received date: January 25, 2016; Accepted date: March 25, 2016; Published date: March 31, 2016

Copyright: ( 2016 , Chaudhury S, et al. This is an open-access article distributed under the terms of the Creative Commons Attribution License, which permits unrestricted use, distribution, and reproduction in any medium, provided the original author and source are credited.

\section{Abstract \\ Background: The co morbidity of substance abuse and schizophrenia is very high and apart from its etiological influence, this affects phenomenology, course and outcome of each other. These can includes onset, course, and association of mood, hostility, anxiety, and severity of symptoms, relapses, and frequent hospitalizations, non- compliance to treatment and poorer psychosocial functioning.}

Methods: The literature (Medline, Psycinfo, Scopus, and Cochrane Database of Systematic Reviews, Google scholar, Index Copernicus International and Pro Quest medical databases) on comorbid substance use and schizophrenia was reviewed.

Results: This review presents recent understanding of this co morbidity, addressing substance use as risk factor and impact on onset for schizophrenia and its early influence over positive, negative or cognitive symptoms dimensions. Individual class of substance of abuse and various other influential factors such as duration of untreated psychosis, treatment course and mortality are related directly or indirectly.

Conclusion: Overall the co-morbidity of substance abuse and schizophrenia causes diagnostic instability, resulting in poor functional outcome; thus needs better awareness and understandings for its prevention, assessment and treatment.

Keywords: Substance use disorder; Schizophrenia; Presentation of symptoms

\section{Introduction}

About half of the patients diagnosed with schizophrenia have comorbid substance use disorders [1-3]. Although it has been suggested that- an important contributor to better outcome in schizophrenia in developing countries like India is low substance use comorbidity [4,5], some studies have found prevalence up to $54 \%$ in India $[6,7]$. More importantly, prevalence is even higher and reaches up to $75 \%$ in patients with first-episode psychosis [8]. A recent meta-analysis showed that patients continue to have this comorbidity and odds of continued cannabis use between 6 months and 10 years following first episode psychosis is 0.56 [9]. Many studies have described the long term course and outcome of comorbid schizophrenia and substance use disorders. They highlight that patients of schizophrenia with comorbid substance use have poorer compliance, frequent psychotic relapses and hospitalizations [10]. This review comprises of an overview about the impact of substance use on acute course of schizophrenia.

\section{Method}

We searched medline, psycinfo, scopus, Cochrane Database of Systematic Reviews, Google scholar Index Copernicus International and Pro Quest medical databases for available full length articles (English). We also included other language articles whose abstracts were available in English. Articles on schizophrenia (keywords: schizophrenia, schizoprenic form, first episode psychosis, early psychosis, recent onset schizophrenia, acute course in schizophrenia, short term schizophrenia) and substance use disorders (keywords: substance [abuse, dependence, use disorder] drug, alcohol, cannabis, cocaine, opiates, stimulants, tobacco) and short term course [keywords: course, short term course, acute course, presentation, short term presentation, acute presentation] were searched for. A total of 2136 articles were returned for different combination searches and across various search engines. Abstracts of the articles were initially read to screen them. About $85 \%$ of the articles were deemed 'not relevant' to the current subject. We included original (full length, brief) and review (systematic, selected) articles that were relevant to the present specific research question. Recently published articles, preferably review articles were chosen over older ones; many cross references were also checked and articles found. Finally we 'selected' a 
total of 64 articles that focused on or had data on influence of substance on acute/short term presentation of schizophrenia.

Table 1 provides a list of all the reviews selected for the present review. Also mentioned is the aspect of emphasis of each review.

Table 2 provides a list of research articles, which particularly aimed at studying impact of substance use disorders on clinical presentation of schizophrenia, selected for the present review. The details on the diagnostic population, type of substance use disorder studied, source of the included sample, the research design and limitations of each of these respective studies are also given.

Table 1: List of reviews selected

\begin{tabular}{|c|c|c|c|}
\hline S.no & Study & Topic & Particular emphasis \\
\hline 01 & Bagot et al. [38] & $\begin{array}{l}\text { Adolescent Initiation of Cannabis Use and Early-Onset } \\
\text { Psychosis }\end{array}$ & Adolescent Initiation \\
\hline 02 & Horsfall et al. [69] & $\begin{array}{l}\text { Psychosocial treatments for comorbid severe mental illnesses } \\
\text { and substance use disorders }\end{array}$ & Psychosocial treatments \\
\hline 03 & Kerner [58] & Comorbid substance use disorders in schizophrenia & A latent class approach \\
\hline 04 & Koskinen et al. [1] & Prevalence of alcohol use disorders in schizophrenia & Prevalence \\
\hline 05 & Koskinen et al. [2] & $\begin{array}{l}\text { Rate of cannabis use disorders in clinical samples of patients } \\
\text { with schizophrenia }\end{array}$ & Prevalence \\
\hline 06 & Kraan et al. [39] & $\begin{array}{l}\text { Cannabis use and transition to psychosis in individuals at ultra- } \\
\text { high risk }\end{array}$ & individuals at ultra-high risk \\
\hline 07 & Le Bec et al. [22] & Cannabis and psychosis: search of a causal link & Etiological models \\
\hline 08 & McLoughlin et al. [64] & Cannabis and schizophrenia & Comprehensive \\
\hline 09 & Meister et al. [8] & $\begin{array}{l}\text { Dual diagnosis psychosis and substance use disorders in } \\
\text { adolescents }\end{array}$ & Adolescents \\
\hline 10 & Myles et al. [9] & Cannabis use in first episode psychosis & Prevalence, time course of further use \\
\hline 11 & Myles et al. [30] & $\begin{array}{l}\text { Cannabis use and earlier age at onset of schizophrenia and } \\
\text { other psychoses }\end{array}$ & Confounding factors \\
\hline 12 & San et al. [67] & $\begin{array}{l}\text { Treatment of schizophrenic patients with substance abuse } \\
\text { disorders }\end{array}$ & Antipsychotic treatment \\
\hline 13 & Thoma et al. [56] & Comorbid substance use disorder in schizophrenia & neurobiological and cognitive underpinnings \\
\hline 14 & Tucker [57] & Substance misuse and early psychosis & An additional emphasis on stimulant drugs \\
\hline 15 & Verdoux et al. [60] & $\begin{array}{l}\text { Impact of substance use on the onset and course of early } \\
\text { psychosis }\end{array}$ & dose-response relationship \\
\hline 16 & Wilkinson et al. $[32,36]$ & Impact of cannabis on the development of psychotic disorders & $\begin{array}{l}\text { temporal relationship, dose-response, and biological } \\
\text { plausibility }\end{array}$ \\
\hline 17 & Wisdom et al. [62] & $\begin{array}{l}\text { Substance use disorder among people with first-episode } \\
\text { psychosis }\end{array}$ & Course and treatment \\
\hline
\end{tabular}

Table 2: List of Original articles selected

\begin{tabular}{|c|c|c|c|c|c|c|}
\hline S.no & Study & Population & Substance & Source of sample & Study design & Limitations \\
\hline 1 & Aich et al. [6] & Schizophrenia & Any & $\begin{array}{l}\text { Tertiary mental } \\
\text { hospital }\end{array}$ & $\begin{array}{l}\text { Compared patients with } \\
\text { and without substance } \\
\text { use }\end{array}$ & $\begin{array}{l}\text { Small sample; cross sectional } \\
\text { design; only inpatients }\end{array}$ \\
\hline 2 & $\begin{array}{l}\text { Allegri et al. } \\
{[28]}\end{array}$ & $\begin{array}{ll}\text { First } & \text { episode } \\
\text { psychoasis } & \end{array}$ & Any & $\begin{array}{l}\text { Community mental } \\
\text { health centers }\end{array}$ & 8 year follow up study & $\begin{array}{l}\text { Sample size of specific drug } \\
\text { groups small }\end{array}$ \\
\hline 3 & $\begin{array}{l}\text { Andreasson et } \\
\text { al. [14] }\end{array}$ & Conscripts & Cannabis & Registry & $\begin{array}{l}\text { 15-year follow-study with } \\
\text { a sample size of } 45,570\end{array}$ & - \\
\hline 4 & $\begin{array}{l}\text { Arseneault et } \\
\text { al. [15] }\end{array}$ & $\begin{array}{l}\text { general population } \\
\text { birth cohort of } 1037\end{array}$ & Cannabis & Registry & $\begin{array}{l}\text { Comparison of groups } \\
\text { varying in age of onset } \\
\text { of cannabis use }\end{array}$ & $\begin{array}{l}\text { Self-report; } \\
\text { assessment }\end{array}$ \\
\hline
\end{tabular}




\begin{tabular}{|c|c|c|c|c|c|c|}
\hline 5 & $\begin{array}{l}\text { Barrowclough } \\
\text { et al. [37] }\end{array}$ & $\begin{array}{l}\text { Recent onset } \\
\text { psychosis }\end{array}$ & Cannabis & $\begin{array}{l}\text { Early Intervention } \\
\text { Services }\end{array}$ & $\begin{array}{l}18 \text { month follow-up } \\
\text { study }\end{array}$ & Insufficient statistical power \\
\hline 6 & $\begin{array}{l}\text { Bersani et al. } \\
{[23]}\end{array}$ & chronic schizophrenia & Cannabis & NA & $\begin{array}{l}\text { Cross-sectional } \\
\text { comparative design }\end{array}$ & Only males; small sample \\
\hline 7 & $\begin{array}{l}\text { Broussard et } \\
\text { al. [47] }\end{array}$ & $\begin{array}{l}\text { first-episode } \\
\text { psychosis patients }\end{array}$ & Any & $\begin{array}{l}\text { Inpatient } \\
\text { psychiatry hospital }\end{array}$ & $\begin{array}{l}\text { Cross sectional } \\
\text { prediction design }\end{array}$ & $\begin{array}{l}\text { Only inpatients; } \\
\text { Small sample }\end{array}$ \\
\hline 8 & $\begin{array}{l}\text { Bühler et al. } \\
{[24]}\end{array}$ & $\begin{array}{l}\text { First episode } \\
\text { schizophrenia }\end{array}$ & Any & General population & $\begin{array}{l}\text { Both retrospective and } \\
\text { prospective }\end{array}$ & $\begin{array}{l}\text { Retrospective assessment of } \\
\text { psychosis onset }\end{array}$ \\
\hline 9 & $\begin{array}{l}\text { Camchong et } \\
\text { al. [42] }\end{array}$ & $\begin{array}{l}\text { Treatment seeker for } \\
\text { cannabis use disorder }\end{array}$ & Cannabis & $\begin{array}{l}\text { Outpatient } \\
\text { department }\end{array}$ & $\begin{array}{l}18 \text { month Longitudinal } \\
\text { assessment of resting } \\
\text { functional connectivity }\end{array}$ & - \\
\hline 10 & $\begin{array}{l}\text { Caton et al. } \\
{[48]}\end{array}$ & $\begin{array}{lr}\text { primary } & \text { psychotic } \\
\text { disorders } & \text { with } \\
\text { concurrent } & \text { substance } \\
\text { use and } & \text { substance- } \\
\text { induced psychoses }\end{array}$ & Any & $\begin{array}{l}\text { Psychiatric } \\
\text { emergency } \\
\text { department } \\
\text { admissions }\end{array}$ & $\begin{array}{l}3 \text { year longitudinal study } \\
\text { comparing primary } \\
\text { psychotic disorders with } \\
\text { concurrent substance } \\
\text { use and substance- } \\
\text { induced psychoses }\end{array}$ & - \\
\hline 11 & $\begin{array}{l}\text { Caton et al. } \\
{[65]}\end{array}$ & -do- & -do- & -do- & $\begin{array}{l}1 \text { year longitudinal study } \\
\text { to assess predictors of } \\
\text { relapse }\end{array}$ & - \\
\hline 12 & $\begin{array}{l}\text { Caton et al. } \\
{[50]}\end{array}$ & -do- & -do- & -do- & $\begin{array}{l}1 \text { year longitudinal study } \\
\text { to assess diagnostic } \\
\text { stability in the two } \\
\text { groups }\end{array}$ & - \\
\hline 13 & $\begin{array}{l}\text { Caton et al. } \\
{[35]}\end{array}$ & -do- & -do- & -do- & $\begin{array}{lr}2 \text { year longitudinal study } \\
\text { comparing primary } \\
\text { psychotic disorders with } \\
\text { concurrent } & \text { substance } \\
\text { use and } & \text { substance- } \\
\text { induced } & \text { psychoses } \\
\text { (esp.gender) } & \end{array}$ & \\
\hline 14 & $\begin{array}{l}\text { Chakraborty et } \\
\text { al. [55] }\end{array}$ & Schizophrenia & Any & $\begin{array}{l}\text { Tertiary mental } \\
\text { hospital }\end{array}$ & $\begin{array}{l}\text { Compared and followed } \\
\text { up patients with and } \\
\text { without substance use }\end{array}$ & $\begin{array}{l}\text { Smaller sample; shorter follow- } \\
\text { up }\end{array}$ \\
\hline 15 & $\begin{array}{l}\text { Dekker et al. } \\
{[29]}\end{array}$ & $\begin{array}{l}\text { non-affective } \\
\text { psychosis }\end{array}$ & Any & NA & Correlational & Retrospective analysis \\
\hline 16 & $\begin{array}{l}\text { Ferdinand et } \\
\text { al. [16] }\end{array}$ & General population & Cannabis & Registry & $\begin{array}{l}\text { a 14-year follow-up } \\
\text { study }\end{array}$ & - \\
\hline 17 & $\begin{array}{l}\text { Fergusso et } \\
\text { al., [17] }\end{array}$ & $\begin{array}{l}\text { General population } \\
\text { cohort }\end{array}$ & Cannabis & Birth registry & $\begin{array}{l}\text { A 25-year longitudinal } \\
\text { study }\end{array}$ & $\begin{array}{l}\text { 'Psychotic symptoms' not } \\
\text { psychosis assessed }\end{array}$ \\
\hline 18 & $\begin{array}{l}\text { Fraser et al. } \\
{[49]}\end{array}$ & $\begin{array}{l}\text { first } \\
\text { psychosis }\end{array}$ & Any & $\begin{array}{l}\text { psychiatric } \\
\text { inpatient service }\end{array}$ & $\begin{array}{l}\text { Comparing substance } \\
\text { induced and primary } \\
\text { psychotic disorders with } \\
\text { concurrent substance } \\
\text { use }\end{array}$ & Small sample \\
\hline 19 & $\begin{array}{l}\text { González- } \\
\text { Ortega et al. } \\
{[61]}\end{array}$ & $\begin{array}{l}\text { first } \\
\text { psychosis }\end{array}$ & Cannabis & $\begin{array}{l}\text { psychiatric } \\
\text { inpatient service }\end{array}$ & 5 year follow-up study & Small sample \\
\hline 20 & $\begin{array}{l}\text { Henquet et al. } \\
{[18]}\end{array}$ & $\begin{array}{lr}\text { young people with } \\
\text { and } & \text { without } \\
\text { predisposition } & \text { for } \\
\text { psychosis } & \end{array}$ & Any & $\begin{array}{l}\text { population based } \\
\text { sample }\end{array}$ & 4 year follow-up study & - \\
\hline 21 & $\begin{array}{l}\text { Hjorthøj et al. } \\
\text { [66] }\end{array}$ & $\begin{array}{l}\text { schizophrenia, bipolar } \\
\text { disorder, or unipolar } \\
\text { depression }\end{array}$ & Any & $\begin{array}{l}\text { register-based } \\
\text { cohort }\end{array}$ & $\begin{array}{l}\text { prospective, comparison } \\
\text { of various diagnostic } \\
\text { groups }\end{array}$ & - \\
\hline 22 & $\begin{array}{l}\text { Kovasznay et } \\
\text { al. [59] }\end{array}$ & $\begin{array}{l}\text { schizophrenia and } \\
106 \text { subjects with } \\
\text { affective psychosis }\end{array}$ & Any & $\begin{array}{l}\text { Inpatient } \\
\text { department }\end{array}$ & $\begin{array}{l}\text { 6-month longitudinal } \\
\text { comparison }\end{array}$ & - \\
\hline 23 & $\begin{array}{l}\text { Mauri et al. } \\
{[26]}\end{array}$ & $\begin{array}{l}\text { first episode of } \\
\text { schizophrenia }\end{array}$ & Any & $\begin{array}{l}\text { Inpatient } \\
\text { psychiatric service }\end{array}$ & Comparative & Cross sectional design \\
\hline
\end{tabular}




\begin{tabular}{|c|c|c|c|c|c|c|}
\hline 24 & $\begin{array}{l}\text { Møller et al. } \\
{[53]}\end{array}$ & & & $\begin{array}{l}\text { Both in- and out- } \\
\text { patients }\end{array}$ & $\begin{array}{l}\text { cross-sectional } \\
\text { comparative study }\end{array}$ & $\begin{array}{l}\text { Small sample; Cross sectional } \\
\text { design }\end{array}$ \\
\hline 25 & $\begin{array}{l}\text { Peralta and } \\
\text { Cuesta (54) }\end{array}$ & schizophrenia & Cannabis & $\begin{array}{l}\text { Inpatient } \\
\text { psychiatric service }\end{array}$ & $\begin{array}{l}\text { cross-sectional } \\
\text { comparative study }\end{array}$ & $\begin{array}{l}\text { Small sample; Cross sectional } \\
\text { design }\end{array}$ \\
\hline 26 & Sara et al. [51] & Psychoses & Any & Inpatient Charts & $\begin{array}{l}\text { Very specific aim of } \\
\text { effect of substance on } \\
\text { diagnostic } \quad \text { stability; } \\
\text { retrospective }\end{array}$ & Retrospective design \\
\hline 27 & $\begin{array}{l}\text { Seddon et al. } \\
\text { [52] }\end{array}$ & $\begin{array}{l}\text { First episode } \\
\text { psychosis }\end{array}$ & Cannabis & $\begin{array}{l}\text { early intervention } \\
\text { services }\end{array}$ & 1 year longitudinal study & - \\
\hline 28 & Sevy et al. [31] & $\begin{array}{l}\text { first episode } \\
\text { schizophrenia }\end{array}$ & Cannabis & Psychiatry setting & $\begin{array}{l}\text { cross-sectional } \\
\text { comparative study }\end{array}$ & $\begin{array}{l}\text { Small sample; Cross sectional } \\
\text { design }\end{array}$ \\
\hline 29 & $\begin{array}{l}\text { Singhal et al. } \\
{[20]}\end{array}$ & $\begin{array}{l}\text { First episode } \\
\text { psychosis }\end{array}$ & $\begin{array}{l}\text { Alcohol and } \\
\text { Cannabis }\end{array}$ & $\begin{array}{l}\text { Inpatient } \\
\text { department }\end{array}$ & 1 year longitudinal study & Small sample size \\
\hline 30 & $\begin{array}{l}\text { Stone et al. } \\
\text { [33] }\end{array}$ & $\begin{array}{l}\text { first-episode } \\
\text { psychosis }\end{array}$ & Cannabis & $\begin{array}{l}\text { Early Intervention } \\
\text { clinic }\end{array}$ & 1 year longitudinal study & - \\
\hline 31 & $\begin{array}{l}\text { Tarricone et al. } \\
\text { [63] }\end{array}$ & $\begin{array}{l}\text { first-episode } \\
\text { psychosis }\end{array}$ & Any & $\begin{array}{l}\text { Community mental } \\
\text { health centers }\end{array}$ & 1 year follow-up study & - \\
\hline 32 & Tien et al. [13] & At risk individuals & Any & Household survey & Cross sectional & $\begin{array}{l}\text { Cross sectional design; } \\
\text { 'psychotic experiences' and not } \\
\text { 'psychosis' }\end{array}$ \\
\hline 33 & $\begin{array}{l}\text { Tosato et al. } \\
\text { [27] }\end{array}$ & $\begin{array}{l}\text { First episode } \\
\text { psychosis }\end{array}$ & Any & $\begin{array}{l}\text { psychiatric } \\
\text { services }\end{array}$ & Cross sectional & Cross sectional design \\
\hline 34 & $\begin{array}{l}\text { van Os et al. } \\
{[19]}\end{array}$ & Psychotic disorder & Any & $\begin{array}{l}\text { Psychiatric setting } \\
\text { as well as general } \\
\text { population }\end{array}$ & 3-year follow-up study & - \\
\hline 35 & $\begin{array}{l}\text { Zammit et al. } \\
{[20]}\end{array}$ & Conscripts & Any & Registry & A retrospective design & $\begin{array}{l}\text { Outcome was only admissions, } \\
\text { retrospective design }\end{array}$ \\
\hline
\end{tabular}

\section{Why comorbid?}

Comorbid substance use, also termed as 'dual diagnosis', has been theorized based on several models like-self-medication, common or bidirectional factor or genetic vulnerability. Although the self-report literature, to an extent, supports the self-medication hypothesis, none of the hypotheses have enough empirical backup [11]. Enthusiasm regarding neurobiological basis for substance use in patients with schizophrenia led to studies that showed frontal cortical and hippocampal dysfunction in schizophrenia leads to disturbances in drug reward; hence suggesting that addictive behaviour as a primary disease symptom of psychosis [12]. However, replicability of these findings is also questionable.

\section{Substance use as a risk factor for schizophrenia}

Among the earlier studies, Tien and Anthony [13] found that alcohol use has been associated with risk of developing schizophrenia. Similarly, in a landmark study Andreasson et al. [14]. Found that cannabis consumption is an independent risk factor for schizophrenia. They found a relative risk for developing schizophrenia among cannabis users compared to non-users was six. Recent literature however reveals that evidence to suggest that substance use may have a causal role in the development of psychopathology is limited to cannabis and not for other substances [11]. Both longitudinal [14-20] and experimental [21] studies have shown that cannabinoids consumption is a definite risk for developing schizophrenia like psychosis. A systematic review found a clear dose-effect relationship between cannabis use and the emergence of psychosis [22]. Regarding other psychoactive substances it has been argued that although alcohol dependence is predictive of psychotic experiences, it (per se) does not cause psychosis. Similarly, although a brief amphetamine-induced psychosis is well documented, the contribution of amphetamine 'causing' schizophrenia per se is dubious. Research on cocaine and opiates as a risk factor for schizophrenia is very limited indeed [11].

\section{Impact on onset}

In more than $60 \%$ of patients diagnosed with comorbid substance use disorder (predominantly cannabis) along with schizophrenia the onset of substance use is before the onset of illness [23-27]. A recent meta-analysis showed that interval between initiation of regular cannabis use and age at onset of psychosis was 6.3 years [9]. Amongst various substances of abuse, cannabis has been found to be associated with an earlier onset of psychosis compared to other drugs/substances [28]. One study found that substance abuse onset and illness onset occurred highly significantly within the same month [24]. This is more specific to cannabis users; in nearly two-thirds of cannabisusing patients, age at most intense cannabis use proceeded the age at onset of first psychosis [29].

Importantly, age at onset of schizophrenia has been found to be nearly 2-3 years earlier in patients with comorbid cannabis 
use disorders compared to non-users, after controlling for various confounding factors [29,30]. Among first episode schizophrenia patients, about three-fourths of cannabis users had the onset of cannabis abuse before the onset of positive symptoms [31]. Further, it has been recently claimed that age at onset of cannabis use moderates the link between cannabis and psychosis, especially schizophrenia [32]. However, it is important to note here that younger age at presentation has been found to be 'not significantly' associated with positive symptoms, negative symptoms and daily functioning [33]. Also, no associations between age at onset and regional grey matter volumes have been found [34]. An important factor related to earlier onset of both substance use and psychosis is increased genetic vulnerability $[23,27]$. Interestingly, in the subset of patients with comorbid substance use disorder, males have an earlier age of onset than females [29,35].

\section{Cannabis use in adolescents and subsequent risk of schizophrenia}

Discussing Cannabis use in adolescents and subsequent risk of developing psychosis is of special importance. Studies have suggested that cannabis use during adolescence is associated with a higher risk of developing psychosis in adulthood; this risk declines when use is later and the association between cannabis-use during adolescence and risk of psychosis is dosedependent [36]. A recent longitudinal study on the impact of cannabis use on clinical outcomes in recent onset psychosis reports that greater dose of cannabis is related with higher depression and anxiety. This study also found that later reductions in cannabis use are associated with improved patient functioning [37]. Another study observed that initiation of cannabis use during adolescence is associated with psychotic symptoms (onset, severity as well as related functional impairment) in a dose-dependent pattern [38]. A recent systematic review and metaanalysis, suggests a tentative doseresponse relationship between current cannabis use and transition to psychosis. This study further emphasizes that only cannabis abuse or dependence is predictive of transition to psychosis in ultra-high risk individuals [39].

A recent review on cannabis and adolescent brain development, suggest that synaptic pruning and white matter development as two processes that are harmfully affected by cannabis use in adolescence and, impairments in these processes underpin the cognitive and emotional deficits related to cannabis use during adolescence [40]. Further, cannabis use was related to reduce gyrification in the prefrontal cortex, which in turn is implicated in several cognitive functions [41]. Reduced functional connectivity between caudal anterior cingulated cortex and dorsolateral and orbitofrontal cortices, found in adolescent cannabis users over time, has been found to predict higher amounts of use and impaired cognitive functioning [42]. Cognitive dysfunction has been found to moderate the associations between cannabis use and vulnerability to subsequent psychiatric morbidity [43]. Preliminary evidence also suggests that males and females might have distinct neurocognitive vulnerabilities for cannabis use in young adults [44].

\section{Impact on duration of untreated psychosis}

A systematic review and meta-analysis inferred an association between shorter duration of untreated psychosis and cannabis use in first episode psychosis patients. This review further suggests that this statement refers to 'use' in terms of current or recent use [45]. However, having ever used cannabis (lifetime use) and the amount of alcohol use were significantly associated with longer duration of untreated psychosis [46-47]

\section{Substance and psychopathology}

Presence of visual hallucinations, higher levels of insight, more severe hostility and anxiety symptoms are important factors that discriminate patients with substance induce psychosis from primary schizophrenia comorbid with substance use disorders $[48,49]$. However, it is found that within one year the diagnosis, substance induced psychosis loses its stability and $25 \%$ of them are diagnosed with schizophrenia [50,41]. Indeed recent findings also suggest that cannabis disorders, more than other substances, predict an increased likelihood, over 2-5 years, of progression to schizophrenia [51].

\section{Positive symptoms}

There is fair bit of heterogeneity in the findings on positive symptoms. While several studies show a significantly increased severity of positive symptoms $[23,24,26,31,46,52]$ in schizophrenia patients with substance use disorder, some studies have found that these patients have significantly lower positive symptoms [53] and some have shown a lack of significant difference between schizophrenia patients with substance use and non-use $[27,54]$. This heterogeneity may be explained by variations in the onset of substance use and psychotic episode. It has been reported that patients whose onset of schizophrenia preceded the beginning of substance abuse had more positive symptoms [23]. Analyzing the sub scores of positive symptoms further, found that substance, especially cannabis; abusers have higher "thought disturbance" and "hostility" scores. Significantly, higher hostility scores were found in patients using cocaine and poly-substance; suggesting that use of other substances might also have an influence on this heterogeneity [26]. Moreover, patients showing greater positive symptoms were poly-substance abusers [23]. Pertinent to mention here is that among poly-substance abusers, cannabis $(49 \%)$ is mostly used followed by alcohol (13\%), and cocaine (4\%) [26].

\section{Negative symptoms}

Although some studies showed no significant difference between schizophrenia patients with substance use and non-use [53], most studies have found that comorbid substance use disorder in schizophrenia is associated with lower and less severe negative symptoms $[23,24,46,54]$. However, significantly increased severity of depression [52,55] manic [52] and anxiety [53] scores were also found in this sub set of patients. Women were found to have greater depression than men [35]. 


\section{Cognitive symptoms}

A few brief-selected reviews $[56,57]$ infer that neurocognitive function might be less disrupted in substance-abusing compared to non-abusing schizophrenia patients. However, some studies have highlighted dysfunction in abstract thinking to be present in dual diagnosis patients at short treatment follow-ups [55].

\section{General functioning}

Over all, using a 'latent class approach', it has been claimed that substance use comorbidity is associated with more acute symptoms and a more severe disease course and not with a specific pattern of positive and negative symptoms [58]. Short term (6-12 month longitudinal) course analysis showed that substance use, especially cannabis, is related to poorer psychosocial functioning $[52,59]$. Moreover it was also found that continued use of cannabis following the episode of psychosis was associated with poorer functional outcome $[52,60]$. Pertinently, cannabis users who abstained have the greatest improvement in symptoms at 1 year compared with continued users and non-users [33]. In depth analysis has shown that, subclinical depressive symptoms have been found to be significantly associated with continued abuse of cannabis during treatment follow-ups; hence associated with worse functioning [61]. Intriguingly, this relationship between substance use and clinical functioning is restricted to schizophrenia patients and not with those with affective psychosis [59]

\section{Impact of a treatment course}

A very few studies have investigated the impact of treatment on early or short term course of schizophrenia, especially first episode schizophrenia. A systematic review found that approximately $50 \%$ of patients become abstinent or significantly reduce their alcohol and drug use after a first episode of psychosis [62]. However, even in short term course of one year, schizophrenia patients with comorbid substance use disorders have been found to have significantly higher rate of hospitalizations (after adjusting for potential confounders) [63]. A 3-month short- longitudinal study found that $27 \%$ of first episode schizophrenia patients with comorbid substance abuse had responded to treatment compared to $35 \%$ of those without comorbid substance use. Specifically, first episode schizophrenia patients with comorbid substance use disorder were found to be less likely responders to olanzapine than those without comorbid substance use disorder, in this study [46]. A recent Cochrane review, which assessed medium term course, shows that not even one form of treatment could show superiority for reduction in cannabis use. Moreover, the meta-analysis found that improvement in psychopathology (i.e. positive and negative symptom scores) over a course of treatment was not significantly different in schizophrenia patients with comorbid substance use disorder than those without [64].

\section{Remission and Predictors}

The predictors of remission in substance using schizophrenia patients and non-users were not significantly different. Lower positive and negative symptoms at baseline, better insight, and a shorter duration of untreated psychosis predict remission in both the groups [65].

\section{Impact on brain}

Specifically in schizophrenia patients using alcohol, structural and functional brain damage is evidenced [56]. Although patients with schizophrenia with or without comorbid cannabis use disorder have smaller volumes of amygdala, putamen, insula, parahippocampus and fusiform gyrus than healthy controls, the cannabis users were found to have larger volumes of the putamen. This study speculates whether a large putamen represents a risk factor for developing cannabis use disorders [34].

\section{Mortality}

In schizophrenia, the all cause-standardised mortality ratios in those with lifetime substance use disorder have been found to be greater than in those without. This study also showed that increase risk of all-cause mortality is independent of the type of substance, single or polysubstance [66].

\section{Treatment strategies}

Factors for remission in psychotic disorders that co-occur with substance use disorders are similar to those reported previously in studies of schizophrenia- better pre-morbid adjustment, smaller duration of untreated psychosis, fair insight into psychotic symptoms, and lower severity of positive symptoms [65]. Among the treatment strategies both pharmacological and psycho-social modes have been proposed. The majority of pharmacological studies suggest the effectiveness of secondgeneration antipsychotics, particularly clozapine [67]. A review found no difference between risperidone and olanzapine, but clozapine had a distinct advantage in reducing psychotic symptoms as well as substance abuse (including smoking). There is some evidence of the usefulness of quetiapine in dually diagnosed patients, particularly using alcohol, cocaine and amphetamine [68]. The psycho-social treatments available for these dual diagnosis patients are motivational interviewing, relapse prevention, cognitive-behavioural therapy, case management, contingency management and skills training [69]. It has been emphasized that these treatments have to be tailored to individual needs.

\section{Reasons for relapses}

A meta-analysis of eight studies showed that the presence of a substance use disorder significantly increases the risk of poor compliance to pharmacological treatment in schizophrenia patients. Further, the meta-analysis of the risk of relapse associated with the presence of substance use disorders including only three studies concluded that having an associated substance use disorder doubles the risk of poor compliance to pharmacological treatment and this comorbidity explains a fifth of all factors involved. Further studies to develop specific 
strategies to better treat patients with schizophrenia and substance use disorder are awaited [70].

\section{Conclusion}

With a high prevalence of comorbid substance use disorders in patients diagnosed with schizophrenia, these subset of patients pose a challenge in the diagnosis and treatment of schizophrenia- from causing diagnostic instability to resulting in overall poor functional outcome. Intense effort is obligatory in developing interventions for substance reduction that are ably adapted for people with psychosis, especially schizophrenia.

\section{Limitation}

As the present paper is a 'selected review' it has inherent limitations compared to a 'systematic review'. Several databases/studies that may be relevant could not have been included; and it lacks a systematic synthesis. Hence, we do not comment on specific study characteristics and quality of research of individual studies and, publication and related biases. Conducting future systematic reviews on the question addressed by the index study would be valuable.

\section{References}

1. Koskinen J, Löhönen J, Koponen H, Isohanni M, Miettunen J (2009) Prevalence of alcohol use disorders in schizophrenia--a systematic review and meta-analysis. Acta Psychiatr Scand 120: 85-96.

2. Koskinen J, Löhönen J, Koponen H, Isohanni M, Miettunen J (2010) Rate of cannabis use disorders in clinical samples of patients with schizophrenia: a meta-analysis. Schizophr Bull 36: 1115-1130.

3. Regier DA, Farmer ME, Rae DS, Locke BZ, Keith SJ, et al. (1990) Comorbidity of mental disorders with alcohol and other drug abuse. Results from the Epidemiologic Catchment Area (ECA) Study. JAMA 264: 2511-2518.

4. Isaac M, Chand P, Murthy $P$ (2007) Schizophrenia outcome measures in the wider international community. Br J Psychiatry Suppl 50: s71-77.

5. Thirthalli J, Venkatesh BK, Gangadhar BN (2008) Psychoses and illicit drug use: need for cross-cultural studies. Acta Psychiatr Scand 118: 86

6. Aich TK, Sinha VK, Khess CR, Singh S (2004) Demographic and clinical correlates of substance abuse comorbidity in schizophrenia. Indian J Psychiatry 46: 135-139.

7. Aich TK, Sinha VK, Khess CR, Singh S (2005) Substance abuse comorbidity in schizophrenia: An inpatient study of course and outcome. Indian J Psychiatry 47: 33-38.

8. Meister K, Burlon M, Rietschel L, Gouzoulis-Mayfrank E, Bock T, et al. (2010) Dual diagnosis psychosis and substance use disorders in adolescents--part 1. Fortschr Neurol Psychiatr 78: 81-89.

9. Myles H, Large M (2015) Cannabis use in first episode psychosis: Meta-analysis of prevalence, and the time course of initiation and continued use. Aust N Z J Psychiatry 50: 208-219.

10. Gouzoulis-Mayfrank E (2004) Dual diagnosis of psychosis and addiction. From principles to practice. Nervenarzt 75: 642-650.

11. Gregg L, Barrowclough C, Haddock G (2007) Reasons for increased substance use in psychosis. Clin Psychol Rev 27: 494-510.
12. Chambers RA, Krystal JH, Self DW (2001) A neurobiological basis for substance abuse comorbidity in schizophrenia. Biol Psychiatry 50: 71-83.

13. Tien AY, Anthony JC (1990) Epidemiological analysis of alcohol and drug use as risk factors for psychotic experiences. J Nerv Ment Dis 178: $473-480$.

14. Andréasson S, Allebeck $P$, Engström A, Rydberg U (1987) Cannabis and schizophrenia. A longitudinal study of Swedish conscripts. Lancet 2: 1483-1486.

15. Arseneault L, Cannon M, Poulton R, Murray R, Caspi A, et al. (2002) Cannabis use in adolescence and risk for adult psychosis: longitudinal prospective study. BMJ 325: 1212-1213.

16. Ferdinand RF, Sondeijker F, van der Ende J, Selten JP, Huizink A, et al. (2005) Cannabis use predicts future psychotic symptoms, and vice versa. Addiction 100: 612-618.

17. Fergusson DM, Horwood LJ, Ridder EM (2005) Tests of causal linkages between cannabis use and psychotic symptoms. Addiction 100: 354-366.

18. Henquet C, Krabbendam L, Spauwen J, Kaplan C, Lieb R, et al (2005) Prospective cohort study of cannabis use, predisposition for psychosis, and psychotic symptoms in young people. BMJ 330: 11.

19. van Os J, Bak M, Hanssen M, Bijl RV, de Graaf R, et al. (2002) Cannabis use and psychosis: a longitudinal population-based study. Am J Epidemiol 156: 319-327.

20. Zammit S, Allebeck P, Andreasson S, Lundberg I, Lewis G (2002) Self-reported cannabis use as a risk factor for schizophrenia in Swedish conscripts of 1969: historical cohort study. BMJ 325: 1199

21. Cortes-Briones J, Skosnik PD, Mathalon D, Cahill J, Pittman B, et al. (2015) $\hat{I}^{\prime \prime} 9-$ THC Disrupts Gamma (î̉)-Band Neural Oscillations in Humans. Neuropsychopharmacology 40: 2124-2134.

22. Le Bec PY, Fatséas M, Denis C, Lavie E, Auriacombe M (2009) Cannabis and psychosis: search of a causal link through a critical and systematic review. Encephale 35: 377-385.

23. Bersani G, Orlandi V, Kotzalidis GD, Pancheri P (2002) Cannabis and schizophrenia: impact on onset, course, psychopathology and outcomes. Eur Arch Psychiatry Clin Neurosci 252: 86-92.

24. Bühler B, Hambrecht M, Löffler W, Heiden W, Häfner H (2002) Precipitation and determination of the onset and course of schizophrenia by substance abuse--a retrospective and prospective study of 232 population-based first illness episodes. Schizophr Res. 54: 243-251.

25. Chaudhury S, Sudarsanan S, Salujha SK, Srivastava K (2005) Cannabis use in psychiatric patients. Medical Journal Armed Forces India 61: 117-120

26. Mauri MC, Volonteri LS, De Gaspari IF, Colasanti A, Brambilla MA, et al. (2006) Substance abuse in first-episode schizophrenic patients: a retrospective study. Clin Pract Epidemiol Ment Health 2: 4 .

27. Tosato S, Lasalvia A, Bonetto C, Mazzoncini R, Cristofalo D, et al. (2013) The impact of cannabis use on age of onset and clinical characteristics in first-episode psychotic patients. Data from the Psychosis Incident Cohort Outcome Study (PICOS). J Psychiatr Res. 47: 438-444

28. Allegri F, Belvederi Murri M, Paparelli A, Marcacci T, Braca M, et al. (2013) Current cannabis use and age of psychosis onset: a gender- 
mediated relationship? Results from an 8-year FEP incidence study in Bologna. Psychiatry Res 210: 368-370.

29. Dekker N, Meijer J, Koeter M, van den Brink W, van Beveren N, et al. (2012) Age at onset of non-affective psychosis in relation to cannabis use, other drug use and gender. Psychol Med. 42: 1903-1911.

30. Myles N, Newall H, Nielssen O, Large M (2102) The association between cannabis use and earlier age at onset of schizophrenia and other psychoses: meta-analysis of possible confounding factors. Curr Pharm Des. 18: 5055-5069.

31. Sevy S, Robinson DG, Napolitano B, Patel RC, Gunduz-Bruce H, et al. (2010) Are cannabis use disorders associated with an earlier age at onset of psychosis? A study in first episode schizophrenia. Schizophr Res. 120: 101-107.

32. Wilkinson ST, Radhakrishnan R, D'Souza DC (2014) Impact of Cannabis Use on the Development of Psychotic Disorders. Curr Addict Rep 1: 115-128.

33. Stone JM, Fisher HL, Major B, Chisholm B, Woolley J, et al. (2014) Cannabis use and first-episode psychosis: relationship with manic and psychotic symptoms, and with age at presentation. Psychol Med. 44: 499-506.

34. Koenders L, Machielsen MW, van der Meer FJ, van Gasselt AC, Meijer CJ, et al. (2015) Brain volume in male patients with recent onset schizophrenia with and without cannabis use disorders. J Psychiatry Neurosci. 40:197-206.

35. Caton $\mathrm{CL}$, Xie H, Drake RE, McHugo G (2014) Gender differences in psychotic disorders with concurrent substance use. J Dual Diagn 10: $177-186$

36. Wilkinson ST, Radhakrishnan R, D'Souza DC (2014) Impact of Cannabis Use on the Development of Psychotic Disorders. Curr Addict Rep 1: 115-128.

37. Barrowclough C, Gregg L, Lobban F, Bucci S, Emsley R (2015) The impact of cannabis use on clinical outcomes in recent onset psychosis. Schizophr Bull 41: 382-390.

38. Bagot KS, Milin R, Kaminer $Y$ (2015) Adolescent Initiation of Cannabis Use and Early-Onset Psychosis. Subst Abus 36: 524-533.

39. Kraan T, Velthorst E, Koenders L, Zwaart K, Ising HK, et al. (2016) Cannabis use and transition to psychosis in individuals at ultrahigh risk: review and meta-analysis. Psychol Med 46: 673-681.

40. Lubman DI, Cheetham A, Yücel M (2015) Cannabis and adolescent brain development. Pharmacol Ther 148: 1-16.

41. Shollenbarger SG, Price J, Wieser J, Lisdahl K (2015) Impact of cannabis use on prefrontal and parietal cortex gyrification and surface area in adolescents and emerging adults. Dev Cogn Neurosci 16: 46-53.

42. Camchong J, Lim KO, Kumra S (2016) Adverse Effects of Cannabis on Adolescent Brain Development: A Longitudinal Study. Cereb Cortex.

43. Huijbregts SC, Griffith-Lendering MF, Vollebergh WA, Swaab H (2014) Neurocognitive moderation of associations between cannabis use and psychoneuroticism. J Clin Exp Neuropsychol 36: 794-805.

44. Crane NA, Schuster RM, Mermelstein RJ, Gonzalez R (2015) Neuropsychological sex differences associated with age of initiated use among young adult cannabis users. J Clin Exp Neuropsychol 37: 389-401.

45. Burns JK (2013) Pathways from cannabis to psychosis: a review of the evidence. Front Psychiatry 4: 128
46. Green Al, Tohen MF, Hamer RM, Strakowski SM, Lieberman JA, et al. (2004) First episode schizophrenia-related psychosis and substance use disorders: acute response to olanzapine and haloperidol. Schizophr Res. 66: 125-135.

47. Broussard B, Kelley ME, Wan CR, Cristofaro SL, Crisafio A, et al. (2013) Demographic, socio-environmental, and substance-related predictors of duration of untreated psychosis (DUP). Schizophr Res 148: 93-98.

48. Caton $\mathrm{CL}$, Drake RE, Hasin DS, Dominguez $\mathrm{B}$, Shrout $\mathrm{PE}$, et al. (2005)Differences between early-phase primary psychotic disorders with concurrent substance use and substance-induced psychoses. Arch Gen Psychiatry. 62: 137-145.

49. Fraser S, Hides L, Philips L, Proctor D, Lubman DI (2012) Differentiating first episode substance induced and primary psychotic disorders with concurrent substance use in young people. Schizophr Res 136: 110-115.

50. Caton $\mathrm{CL}$, Hasin DS, Shrout PE, Drake RE, Dominguez $\mathrm{B}$, et al. (2007) Stability of early-phase primary psychotic disorders with concurrent substance use and substance-induced psychosis. $\mathrm{Br} \mathrm{J}$ Psychiatry. 190: 105-111.

51. Sara GE, Burgess PM, Malhi GS, Whiteford HA, Hall WC (2014) The impact of cannabis and stimulant disorders on diagnostic stability in psychosis. J Clin Psychiatry 75: 349-356.

52. Seddon JL, Birchwood M, Copello A, Everard L, Jones PB, et al. (2015) Cannabis Use Is Associated With Increased Psychotic Symptoms and Poorer Psychosocial Functioning in First-Episode Psychosis: A Report From the UK National EDEN Study. Schizophr Bull 154.

53. Møller T, Linaker OM (2004) Symptoms and lifetime treatment experiences in psychotic patients with and without substance abuse. Nord J Psychiatry 58: 237-242.

54. Peralta V, Cuesta MJ (1992) Influence of cannabis abuse on schizophrenic psychopathology. Acta Psychiatr Scand 85: 127-130.

55. Chakraborty R, Chatterjee A, Chaudhury S (2014) Impact of substance use disorder on presentation and short-term course of schizophrenia. Psychiatry J 2014: 280243.

56. Thoma P, Daum I (2013) Comorbid substance use disorder in schizophrenia: a selective overview of neurobiological and cognitive underpinnings. Psychiatry Clin Neurosci 67: 367-383.

57. Tucker $P$ (2009) Substance misuse and early psychosis. Australas Psychiatry 17: 291-294.

58. Kerner B (2015) Comorbid substance use disorders in schizophrenia: a latent class approach. Psychiatry Res 225: 395-401.

59. Kovasznay B, Fleischer J, Tanenberg-Karant M, Jandorf L, Miller AD, et al. (1997) Substance use disorder and the early course of illness in schizophrenia and affective psychosis. Schizophr Bull 23: 195-201.

60. Verdoux H, Tournier M, Cougnard A (2005) Impact of substance use on the onset and course of early psychosis. Schizophr Res 79: 69-75.

61. González-Ortega I, Alberich S, Echeburúa E, Aizpuru F, Millán E, et al. (2015) Subclinical depressive symptoms and continued cannabis use: predictors of negative outcomes in first episode psychosis. PLoS One. 10: e0123707.

62. Wisdom JP, Manuel JI, Drake RE (2011) Substance use disorder among people with first-episode psychosis: a systematic review of course and treatment. Psychiatr Serv 62: 1007-1012. 
63. Tarricone I, Boydell J, Panigada S, Allegri F, Marcacci T, et al. (2014) The impact of substance use at psychosis onset on First Episode Psychosis course: results from a 1 year follow-up study in Bologna. Schizophr Res. 153: 60-63.

64. McLoughlin BC, Pushpa-Rajah JA, Gillies D, Rathbone J, Variend H, et al. (2014) Cannabis and schizophrenia. Cochrane Database Syst Rev 10: CD004837.

65. Caton $\mathrm{CL}$, Hasin $\mathrm{DS}$, Shrout $\mathrm{PE}$, Drake RE, Dominguez $\mathrm{B}$, et al. (2006) Predictors of psychosis remission in psychotic disorders that co-occur with substance use. Schizophr Bull 32: 618-625.

66. Hjorthøj C, Østergaard ML, Benros ME, Toftdahl NG, Erlangsen A, et al. (2015) Association between alcohol and substance use disorders and all-cause and cause-specific mortality in schizophrenia, bipolar disorder, and unipolar depression: a nationwide, prospective, register-based study. Lancet Psychiatry 2: 801-808.
67. San L, Arranz B, Martinez-Raga J (2007) Antipsychotic drug treatment of schizophrenic patients with substance abuse disorders. Eur Addict Res 13: 230-243.

68. Murthy P, Chand P (2012) Treatment of dual diagnosis disorders. Curr Opin Psychiatry 25: 194-200.

69. Horsfall J, Cleary M, Hunt GE, Walter G (2009) Psychosocial treatments for people with co-occurring severe mental illnesses and substance use disorders (dual diagnosis): a review of empirical evidence. Harv Rev Psychiatry 17: 24-34.

70. Ameller A, Gorwood P (2015) Attributable risk of co-morbid substance use disorder in poor observance to pharmacological treatment and the occurrence of relapse in schizophrenia. Encephale 41: 174-183. 